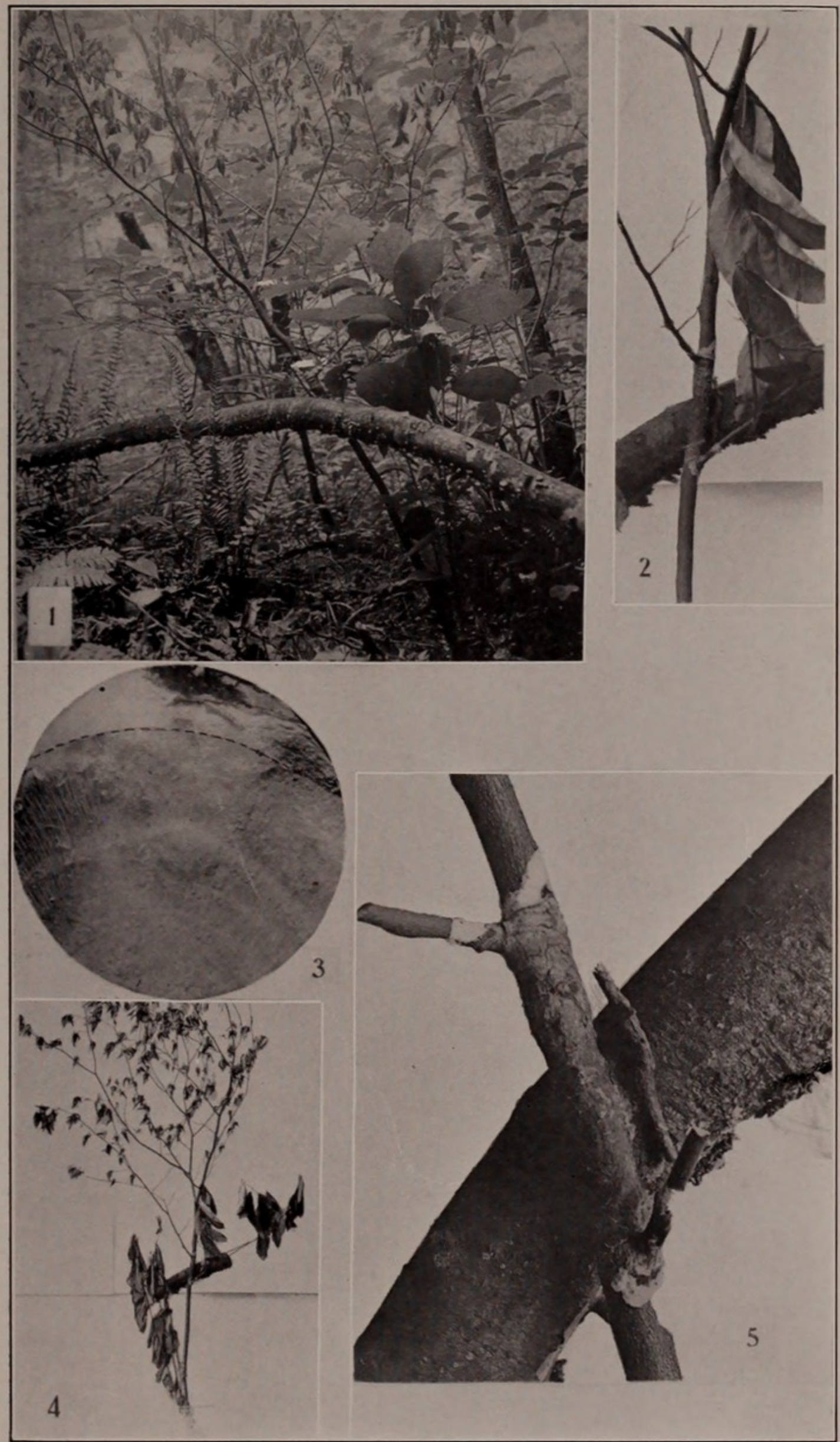





\section{TWO NEW SPECIES OF WATER MOLDS}

(With Plates 146-148, Containing 38 Figures)

\section{W. C. CoKer}

Since the publication of my third new species of $A$ chlya $a^{1}$ in I9I2 a continued study of the occurrence and periodicity of the Saprolegniaceae in Chapel Hill, has discovered two other new and remarkable forms of that family.

The first of these was met with as long ago as March, I9I I, and it has been found twenty-five times since. Pure cultures on various media, generally from a single spore, have been kept under observation for over three years. So puzzling is the form that after preparing a description of it in I9I2 it was decided to continue collections and experiments for another year before publication. The difficulty arises from the fact that our plant combines in a most confusing manner the characters of both Achlya and Saprolegnia, and a rigid interpretation of these genera as at present defined would exclude it from both. As the formation of a new genus in such a case could not simplify matters, and as the genera Achlya and Saprolegnia are sufficiently distinct except for this narrow point of contact, it would seem much better to retain them and admit the variations. The case is not unlike the situation in the two genera Puccinia and Uromyces, where forms are known that combine the characters of both. As the proliferation of the sporangia is usually of the Achlya type I have decided to refer this form to the genus Achlya and to define it as follows:

\section{Achlya paradoxa sp. nov.}

Plant delicate; hyphae straight, slender, and little branched, the larger threads having a diameter of about $37 \mu$; many much smaller, the average being about IO-I $5 \mu$; sporangia plentiful at all stages, narrowly club-shaped and largest at the distal end which is about $55 \mu$ in diameter, rounded, and furnished with a distinct but short papilla; secondary sporangia formed usually

1 Mycologia $4: 325$. I9I2. 
by cymose branching beneath the old ones, but occasionally also by proliferation through the empty ones, exactly as in Saprolegnia. Spores formed in several rows as in Saprolegnia and Achlya, on emerging all ciliated, but varying greatly in behavior-some swimming away as a rule, others remaining attached to the tip of the sporangium; oogonia produced on the tips of short lateral branches, usually near the base of the main hyphae, sometimes intercallary; their walls smooth and without pits, except for the thin places where the antheridia are attached; oospores usually two, often four and rarely one or eight; their diameter from 22 to $37 \mu$, averaging about $30 \mu$; antheridia always present, generally several on each oogonium, short club-shaped and terminating slender branches of diclinous origin which show a decided tendency to twine about the oogonial branches; antheridial tubes enter the oogonia, run among the eggs, and probably fertilize them.

In fig. I the sporangia are shown in a group after the manner of Achlya. The bending of the sporangia that is quite noticeable in this figure is characteristic, though not always so pronounced.

In figs. 2 and 3 are shown the proliferation of sporangia by both the Achlya and Saprolegnia methods on the same thread. The latter method is rare, but when it does occur is exactly as in Saprolegnia a condition that has not been observed in any other species of Achlya. In fact I know of no reference in the literature to internal proliferation of any kind in Achlya except by Peterson ${ }^{2}$ who says: "Thus I have seen zoosporangia which had proliferated in undoubted species of Achlya." ${ }^{3}$ The behavior of the spores on emerging is remarkable and very variable. In regard to their action I shall give the following quotation from my notes made at the moment of observation:

The spores emerge somewhat elongated and may be seen to bend backward at the ends and fuse into a pear-shaped spore, as is the case in Leptolegnia. The spores are very sluggish and most of them fall down immediately around the sporangium mouth and encyst, also a lot are often left in a group that sticks to the sporangium mouth, giving the effect of Achlya.

I find cases where all, or nearly all, of the spores group themselves at the mouth exactly as is typical for Achlya. When conditions are unfavorable the spores sometimes do not emerge at all and in such cases they sprout in position.

Noticed two sporangia empty near together. In one the spores grouped themselves at the mouth of the sporangium just as in Achlya, except that a

2 Ann. Mycologici 8: 520. I910.

3 The extreme rarity of such a phenomenon in Achlya would make it desirable that such an observation be accompanied by figures. 
few of the outermost gently rocked themselves away a little distance from the main mass and then settled down. The spores that remained in a mass at the tip of the sporangium also showed a very slight rocking movement, thus proving the presence of cilia, but in a couple of minutes they became quite still. In the other sporangium the spores charged out with great rapidity and everyone dashed rapidly away.

A sporangium emptied at $I I: I_{3}$ and all the spores sank slowly to the bottom of the dish separating themselves considerably by a gentle rocking motion. After settling, individuals would move spasmodically at intervals, turning and jerking, but none swam actively or any distance. This interrupted movement continued for at least a half hour after emergence.

The existence of cilia thus indicated by the behavior of the spores was demonstrated by treatment with potassium iodide solution at the moment of emergence. A sporangium so treated is shown in fig. 4. All the spores can be distinctly seen to have cilia. From these observations it will be seen that the behavior of the spores in Achlya paradoxa has no parallel in the genus.

In figs. $5,6,7,8$, a series of oogonia are shown with normal variation. Oogonia without stalks and with their bases formed from a section of a hypha are not at all rare (fig. 5.) The variation in size of the oogonia is extreme. The smallest are not more than $23 \mu$ in diameter, the largest may reach $74 \mu$.

Slender upgrowths into the oogonium from the partition below are occasionally seen. Such growths often appear in other species of Saprolegnia and Achlya, but, while they give the effect of antheridial tubes, they are usually quite functionless. The antheridia themselves are peculiar. They are sudden enlargements of the tips of the antheridial branches and are short, thick and tuberlike. They often proliferate, and usually by growth from near the base of the antheridial cells themselves. These outgrowths are then cut off as separate antheridia (figs. 7 and 8). When first formed the antheridia are well filled with protoplasm and contrast strongly with the almost colorless branches that bear them. Later the antheridia appear almost empty as if they had discharged their contents into the eggs. This, however, was not actually observed. Chlamydospores unlike the oogonia, are not rare, but appear plentifully, though not densely, in almost all cultures. The majority terminate short branches and approximate the oogonia in size, shape and position (fig. 9): others are arranged in chains (fig. Io) which are usually curved or contorted. 
Elongated and irregular forms are also produced from somewhat swollen and knotted segments of the hyphae.

Under ordinary cultural conditions such as on flies, ant larvae, gnats, mushroom grubs, etc., in water there is usually no sexual reproduction. Out of a hundred cultures perhaps one would show a few oogonia. A number of experiments have been made to induce the formation of oogonia. The results of some of these are as follows:

On a bit of whole egg agar in distilled water: Growth vigorous and healthy. Sporangia abundant, emptying normally and proliferating laterally from below. No oogonia or chlamydospores.

On a bit of whole egg agar in distilled water: Growth vigorous, reaching a diameter of $4 \mathrm{~cm}$. Sporangia slow to form, but after full growth appearing rather plentifully. Chlamydospores of usual shape present, but not plentiful. No oogonia.

On a bit of hard boiled egg yolk in distilled water: Growth vigorous, reaching a diameter of $4 \mathrm{~cm}$. Sporangia abundant and formed earlier than in culture above. Chlamydospores plentiful. Oogonia present, but scarce. Antheridia of diclinous origin. As this was a culture from a single spore, the presence of antheridia proves that the plant is not dioecious.

On a bit of whole egg agar in spring water: Growth vigorous and strong. Many chlamydospores. No sexual reproduction.

On fly in spring water: Growth vigorous. Many sporangia, all proliferating from side below as in Achlya. No chlamydospores or oogonia.

On corn meal agar: Growth extensive, filling dish. Aerial branches nearly reaching cover, but not dense. Only chlamydospores present.

In 5 per cent. maltose + o. I per cent. peptone solutions mixed half and half: Growth vigorous and healthy. A few small sporangia were formed, but the spores were only imperfectly discharged. Also a few of the characteristic knob-like chlamydospores.

On corn meal agar in tightly stopped sterile bottle: Growth vigorous, extending across bottle and making a mold-like aerial growth an inch high. On examination there were found only single chlamydospores, most of which were quite empty, they having sprouted by a slender thread about $3 \mu$ in diameter. In fact all the growth was remarkably slender $(3 \mu$ in diameter), enlarging to normal size only just below the chlamydospores.

On corn meal and egg yolk agar: Growth very strong, covering dish and developing abundant aerial hyphae that reach the cover. No reproduction of any kind.

The following six cultures were all made on ant larvae in distilled water with the salt added as indicated:

In o.I per cent. $\mathrm{KNO}_{3}$ : Growth good. Normal sporangia, discharging and spores taking second swim. Many good chlamydospores of usual shape, the larger ones having a tendency to form the cross wall some way up from the base. No sexual reproduction. 
In o.1 per cent. $\mathrm{KH}_{2} \mathrm{PO}_{4}$ : Growth good. Many normal sporangia discharging, and spores taking second swim. Many chlamydospores. No sexual reproduction.

In o.I per cent. $\mathrm{Na}_{2} \mathrm{HPO}_{4}$ : Growth good. Many normal sporangia discharging, and spores taking second swim. A good many chlamydospores, but not so numerous as in the preceding cultures. No sexual reproduction.

In o.I per cent. $\mathrm{K}_{2} \mathrm{SO}_{4}$ : Growth slight. Culture infested with fungus. Sporangia formed but not discharging. A few chlamydospores. No sexual reproduction.

In o.I per cent. $\mathrm{Ca}_{3}\left(\mathrm{PO}_{4}\right)_{2}$ : Growth good. Many normal sporangia discharging, and spores taking second swim. Many chlamydospores of usual shape. No sexual reproduction.

In o.I per cent. $\mathrm{Ca}\left(\mathrm{NO}_{3}\right)_{2}$ : Growth good. Many normal sporangia discharging, and spores taking second swim. Many chlamydospores. No sexual reproduction.

The following seven cultures were all made on hard boiled egg yolk in distilled water with the chemical added as indicated:

In o.I per cent. $\mathrm{KNO}_{3}$ : Strong growth. No sporangia. A few good chlamydospore. No sexual reproduction.

In o.I per cent $\mathrm{KH}_{2} \mathrm{PO}_{4}$ : Growth good. A very few sporangia with normal discharge. No chlamydospores or sexual reproduction.

In o.I per cent. $\mathrm{Na}_{2} \mathrm{HPO}_{4}$ : Strong growth. Abundant sporangia proliferating repeatedly, and discharging normally. A very few chlamydospores. No sexual reproduction.

In o.I per cent. $\mathrm{K}_{2} \mathrm{SO}_{4}$ : Strong growth. Sporangia plentiful. Chlamydospores abundant. No sexual reproduction. One sporangia was seen discharging. The emergence was rather slow, and the last few spores were very slow and showed obvious swimming movements in the sporangium on escaping. About a dozen clung to the tip of the sporangium. The others spread in a loose flock, showing slow movements, and every now and then one would swim briskly away.

In o.I per cent. $\mathrm{Ca}_{3}\left(\mathrm{PO}_{4}\right)_{2}$ : Strong growth. Many sporangia, quite normal. A very few chlamydospores. No sexual reproduction. Several sporangia seen to discharge. Six spores detached themselves at different points and moved away, soon stopped and settled to the bottom. All others remained attached in a pretty solid mass to the tip of the sporangium. In another case four were detached. In another case six were detached.

In o.I per cent $\mathrm{Ca}\left(\mathrm{NO}_{3}\right)_{2}$ : Very little growth. A good many chlamydospores. Nothing else.

In o.I per cent. $\mathrm{K}_{3} \mathrm{PO}_{4}$ : Strong growth. Abundant sporangia. Many good chlamydospores that look exactly like oogonia initials, and a good many smaller branches that suggest antheridial branches, but no oogonia.

The genus Pythiopsis has until now included but one species, P. cymosa, discovered in Germany by De Bary. ${ }^{4}$ It has been recognized only one since, it seems, when Humphrey ${ }^{5}$ found it

4 Bot. Zeit. 46: 63 . 1888.

5 The Saprolegniaceae of the United States. Transactions Amer. Philos.

Soc. 17 : part 3 . 
at Amherst, Mass. From two figures given by Hine ${ }^{6} \mathrm{I}$ am inclined to think that he had before him the sporangia of this plant, but that was before it had been described, and he did not get any further with it. I have found this species a good many times in Chapel Hill in springs, brooks and marshes; for example, in Terra Cotta Spring, Glen Burnie Farm (Jan. 15, 1913), twice in a marshy place near the above spring (once on Jan. ${ }_{5} 5$ and again on Jan. 30, I9I3), in Howell's Spring (Jan. 7, I9I4), in Howell's spring and the brook below (March 3, I9I4), etc. As the plant has so far been rather inadequately figured and described I shall give a short account of it before describing the new species. The sporangia, oogonia and antheridia are well shown by De Bary and Humphrey, but variations occur that were not observed by them. The antheridial cells, as formed in about one half the oogonia are unique in position. They arise by the enlargement of the hypha immediately below the oogonium and the growth of this segment along the base of the oogonium for a short distance. A tube is formed near the septum and enters to the egg. As the antheridial cell is in close contact with the oogonial wall from the septum out, the position of the septum becomes obscured and the oogonium seems to be seated at maturity on a large, swollen, basal cell. Under high power, however, the original septum may be seen as a somewhat thicker disc. This form of antheridium, as shown in fig. I and in one of the two in fig. 2, is not exactly illustrated in either De Bary's or Humphrey's figures. From this strictly basal and closely pressed antheridium we have in the remaining half of the oogonia all sorts of variations. The antheridium may be elevated on a stalk that varies from nothing to half the length of the oogonium and in very rare cases the antheridium may be even of diclinous origin (figs. 5 and 6). The appearance of several antheridia on one oogonium is of rather frequent occurrence in my cultures. This is not recorded by De Bary or Humphrey. From figures 3 to 7 an idea may be gained of the variations observable in both antheridia and oogonia. De Bary does not give the size of the oospores. I find them to vary from 16.5 to $24 \mu$, with an average of about $19.5 \mu$. This is a little larger than the figures given by Humphrey.

${ }^{6}$ Figs. 6 and 7, plate 5, Amer. Micr. Journal I. 1878. 
The remarkable intercalary oogonium shown in fig. 8 is unique. Its single egg was 27.8 by $50 \mu$ in size and a large number of oildrops were grouped at each end. An antheridial cell was also cut off at each end, but no antheridium could be made out.

The peculiar jelly-like outer layer that De Bary noticed on the oogonia in October cultures was also seen by Humphrey in a few cases. By careful observation I have been able to make out this layer in the majority of young oogonia. It is probably present on all at a certain stage, but in clean cultures free from bacteria is very hard to trace. Its presence and outline is hardly discernable, except for the bacteria and other minute particles that stick to it. As remarked by Humphrey it is hardly possible that this hyalin gelatinous outer sheath can be a "periplasm" secreted from the oogonium contents, as De Bary suggests. It is more apt to be due to the gelatinization of a thin outer layer of the wall of the oogonium.

In a typical clean culture in springwater on a mushroom grub the sporangia varied from 37 to $56 \mu$ in diameter, the majority being from 44 to $48 \mu$ broad.

In figures 9 and Io are shown sporangia of usual appearance. When the sporangia proceed at once to the formation of spores the discharge is usually at the tip (fig. 9). If a rest occurs, the immergence tube is as apt to appear at the base, as shown in fig. II. After the first sudden release of pressure the spores do not rush out as in Achlya and Saprolegnia, but emerge much more quietly as they find the opening. The last ones often swim around a long time in the sporangium before finding an exit. The spores are pear-shaped, with two cilia at the small end. On coming to rest they round up. In fig. 12 are shown three normal spores and an anomalous double one with four cilia. This is not a case of fusion after emergence, but of imperfect segmentation of the protoplasm. I have often seen in species of Achlya the discharge of large lumps and iregular masses of protoplasm from the sporangia as a result of imperfect segmentation. Sometimes the whole mass may in Achlya be thus discharged as a single long, contorted rope (see below p. 300). Leitgeb ${ }^{7}$ shows similar masses of protoplasm in Saprolegnia monoica (under the name of Diplanes).

7 Jahrb. für Wiss. Bot. $7: 357$, plate 24 , figs. $3-5$. 1869 . 
Resting bodies of more or less globular shape are formed in quantity and are often arranged in chains (fig. II). After a rest these also form zoospores.

Our new species of Pythiopsis has appeared eight times in collections made in the neighborhood of Chapel Hill. It was first obtained on Feb. 29th, I9I2, from collections made at intervals along the brook that flows from the spring about Ioo yards to the northwest of Dr. Archibald Henderson's residence. A tumbler of water was taken at each place with a little mud and any algae and dead leaves, twigs, etc., that happened to be present. Ant larvae were floated on the surface of the water of each tumbler and in four of these appeared a species of Pythiopsis that was found to be new. It was also found on the same day in a springy marsh on the south side of Glen Burnie Meadow and appeared subsequently in the brook in Battle's Park (March 18, I9I2), in the branch south of the South Building, U. N. C. (March 25, I9I2), and again in the Glen Burnie Meadow Marsh (May I3, I912). The plant was separated from other fungi present and was grown in pure cultures for about six months. I have named the species in honor of the late Dr. James Ellis Humphrey, author of "The Saprolegniaceae of the United States," whose work has been of great assistance to all students of this group in America. The species may be defined as follows:

\section{Pythiopsis Humphreyana sp. nov.}

Vegetative growth of long, slender, sparingly branched hyphae of about II to I $4 \mu$ in diameter throughout, stouter in the neighborhood of the reproductive bodies, after maturity disorganizing rather quickly; sporangia varying in shape from spherical, oval or pyriform to elongated, tapering and irregular forms, discharging by a short or rather long papilla and usually proliferating from below in a cymose manner; spores monoplanetic, pear-shaped and with two cilia, about $8.9 \mu$ in diameter on coming to rest; oogonia generally borne exactly like the sporangia and not to be distinguished from these when young, apical and often in groups by cymose branching, usually spherical with a basal neck, sometimes pear-shaped and rarely longer and more irregular, varying greatly in size, diameter from 33 to $89 \mu$, averaging about $43 \mu$; wall always smooth and unpitted, about I.4 $\mu$ thick; oospores generally one, occasionally two and very rarely four, centric, 
diameter from 24 to $40 \mu$ averaging about $30 \mu$, the wall about $2 \mu$ thick, not so nearly filling the oogonium as in P. cymosa; antheridia short-clavate, terminating a stalk that usually arises from immediately below the oogonium, but sometimes of more distant origin, or rarely diclinous, one, two or occasionally more on every oogonium and generally applied to its top or distal half, with an antheridial tube which reaches and apparently fertilizes the egg; resting bodies resembling sporangia or oogonia present in quantity, after a rest forming spores or germinating with tubes.

The species is sharply separated from $P$. cymosa by the much larger and always smooth oogonia, larger eggs, larger sporangia, absence of strictly basal antheridia and presence of elongated forms of sporangia. Illustrations of the globular type of sporangia, which are the first to appear in clean and vigorous cultures are given in figures $I$ and 2 . They are of the same appearance as those of $P$. cymosa. The papilla is usually formed at the tip when growth is active, but if there is a rest it is as apt to be formed at any other point (figs. 2, 7, I0). Intermediate and elongated forms are shown in figs. 4 to Io. As in P. cymosa the internal pressure is dissipated before the last spores emerge and it is often many minutes before all find the exit. As shown in the figures, the papilla may be quite abrupt or may gradually taper into the body of the sporangium.

The oogonia are often closely associated with the sporangia (figs. 2, II and I2), but the more common arrangement is a terminal oogonium on a rather short lateral branch as shown in fig. I3, with a single stalked antheridium arising from immediately below it. The antheridial branch almost invariably carries but a single antheridium, which is short, thick and densely filled with protoplasm. The antheridial tube is quite conspicuous and its behavior is such that there is scarcely any doubt that fertilization takes place. The protoplasm of the antheridium passes into the tube and soon after no protoplasm or tube can be seen, indicating the discharge of the former and collapse of the very thin-walled tube. The tubes are distinctly shown in figs. II, I2 and I 5 .

Oogonia with two eggs are not very rare. One of these with two antheridia is shown in fig. I4. Oogonia with four eggs were seen twice. One of these, of anomalous shape, is shown in fig. I6. The occurrence of more than one egg in the oogonium of $P$. 
cymosa is quite rare. Humphrey saw two eggs only once and my cultures of that species have not produced any such oogonia. De Bary says that as many as three eggs may occur in $P$. cymosa but their appearance is evidently of great rarity.

In order to judge of the significance of the peculiar behavior of the spores in Achlya paradoxa it will be useful to review the variations in behavior in sexual reproduction in the Saprolegniaceae as recorded in the literature.

In the case of Achlya a departure from or modification of the usual grouping of the spores at the sporangium tip has been recorded in a few instances. In the first place it must be remembered that the spores in this genus are not perfectly quiescent during and immediately after emergence. A slight amoeboid motion is observable at all times from their initial formation to the appearance of the encysting membrane. Added to this is a certain feeble jerking and rotation due to the presence of cilia, that has been recorded by several observers since Cornu ${ }^{8}$ first described it in 1872 . On page II of his monograph Cornu says that these cilia have just enough agility to cause the escape of the spores from the sporangium, thus implying that they are the cause of the escape, a point that has been considerably discussed and which I shall take up at another time. The presence of cilia on the emerging spores of Achlya is strongly asserted by Hartog $^{9}$ who also predicts that they will be found in all species of Achlya and Aphanomyces. ${ }^{10}$

$\mathrm{He}$ also says in the first of these papers that the spores of Achlya after forming a ball revolve on their long axils for a short time before the cyst is formed, and that sometimes a few spores will detach themselves and swim away a short distance. In the second paper he says that "When the sporange is discharged near the margin of the hanging drop, or in a thin layer of water on a slide, we constantly see single spores escape from the mass, swim away, and encyst apart." This important observation has been frequently overlooked by subsequent workers, but I can confirm it

8 Monographie des Saprolegniées. Ann. Sci. Nat. V. I5: 5. 1872.

9 Quart. Jour. Micr. Sci. 35: 427. 1887 .

10 Ann. Botany 2: 201. 1888. 
positively for Achlya caroliniana. In this case if the sporangium is put on the slide in a very thin layer of water the spores will swim slowly apart on emerging and scatter themselves over a limited area near the mouth of the sporangium. By addition of iodine solution the cilia were clearly seen. In the case of Achlya De Baryana $^{11}$ I have recorded the occasional breaking up of the spore mass into scattered groups, but I have not seen any swimming motion in that species. Humphrey in his monograph also demonstrated the presence of cilia on the escaping spores of Achlya americana. It will be noted, however, that in none of these cases do any of the spores swim away regularly and under ordinary circumstances. In this respect Achlya paradoxa is unique.

In case of bacterial contamination, or foulness from any cause, or where the parts are put in liquid nutrient media, there is strong tendency for the spores to be retained in the sporangium, or if discharged for them to sprout at once without a second swimming stage. There has arisen a loose way of speaking of all sporangia when the spores are retained, or even in part retained, as "Dictyosporangia" a term that should be used, only when spores emerge through the wall of the sporangium and escape for (what is homologous with) the second swimming stage. As one might expect, there is variation in Dictyuchus itself in this respect, the spores frequently sprouting by the Aplanes method (see below). Variations in the discharge and behavior of the spores are recorded in the following cases:

Achlya aplanes Maurizio: Flora 79: 109. I894. The behavior of the spores in this case is very peculiar. There is no swimming stage, the spores on emerging sprouting into tubes. Frequently they do not emerge at all, but remain in the sporangium and sprout there.

Achlya caroliniana Coker: Bot. Gaz. 50:381. I910. The spores may be retained and sprout as in Aplanes, or under certain circumstances may emerge in a motile condition.

Later observation by me shows that under certain conditions as an egg yolk in I per cent. $\mathrm{KN}_{2} \mathrm{PO}_{4}$ the spores may not stick to the sporangium mouth, but fall to the bottom in open order.

11 Mycologia 4 : 319. 1912. 
Achlya De Baryana Humphrey (Achlya polyandra De Bary): Coker, Mycologia 4: 319. I9I2. Figs. 7 and 8, of plate 78 , show reduced sporangia with spores in a single row, the spores emerging exactly as in Dictyuchus. They also frequently sprout as in Aplanes.

Achlya glomerata Coker: Mycologia 4: 325. I912. In fig. 7 , plate 79, is shown a sporangium with the spores sprouting as in Aplanes.

Achlya polyandra Hildebrand: Ward, Quart. Jour. Micr. Sci., 23: 272. I883. In plate 22 , fig. 8 , is shown a sporangium with the spores emerging just as in Dictyuchus. The retention of the spores in this case he was able to bring about by poor aeration, i. e., placing the culture in on air tight chamber.

Achlya prolifera (Nees) De Bary: Bot. Zeit. 10: 473. 1852. In plate 7 , fig. 28 , is shown the sprouting of the spores at the mouth of the sporangium, the second swimming stage omitted. In all the seven species of Achlya that I have studied the second swimming stage may be easily suppressed.

Achlya racemosa Hildebrand: Pringsheim, Jahrb. für Wiss. Bot. 9: 191. 1873. In plate 22, figs. I, 2 and 3 , are shown sporangia emptying exactly as in Dictyuchus. Under the name of Achlya lignicola, which is now regarded as a depauperate condition of A. racemosa, Hildebrand figures a sporangium with many of the spores remaining undischarged (Jahrb. für Wiss. Bot. 6: 249, plate I6, fig. 2. I867).

Aphanomyces stellatus De Bary: Sorokin, Ann. Sci. Nat. VI. 3 : 46. 1876 . In plate 7 , figs. Io and 18 , are shown sporangia discharging their spores in the exact manner of Dictyuchus. He also shows sprouting at the mouth of the sporangium, and sporangia with spores in more than one row. See also Humphrey (Saprolegniaceae of the U. S., p. 79) for omission of second swimming stage.

Aplanes androgynus (Archer) Humphrey (=Aplanes Braunii De Bary): Reinsch, Jahrb. für Wiss. Bot. II : 283. 1877.

Under the name of Achlya Braunii, Reinsch states positively 
that sporangia occur which show cell nets after the escape of the spores. He also says that in most cases after the emergence of the spores the cell nets are not visible, indicating that they disappear soon. His implication throughout is that the spores always escape as in Dictyuchus, and one of his figures (fig. 5, plate 14) clearly shows this method. However, in fig. 2 he shows two sporangia attached to an oogonium which are empty and show distinct openings for the discharge of the spores. In fact Reinsch did not observe at all the "Aplanes type" of spore germination as De Bary later described it (Bot. Zeit. 46: 651. I888). When we remember that De Bary speaks of the sporangia as of great rarity, it seems to me that we are entirely unjustified in asserting that the spores of Aplanes have no swimming stage. All of Reinsch's testimony is the other way, and as Fischer says (Kryptogamen Flora von Deutschland, etc., p. 367. I892) there can be no doubt that Reinsch's plant and De Bary's are the same. In his description of the genus Fischer admits that net sporangia (as in Dictyuchus) seem also to occur occasionally.

Apodachlya pirifera Zopf: Nova Acta Kel. Leop. Carol. Akad. der Naturforscher $52: 3$ I3. I888. The spores normally encyst at the mouth of the sporangium and then emerge for a swimming stage as in Achlya. However, they may, on occasion, swim away in emerging, or they may encyst in part in the sporangium.

Dictyuchus monosporus Leitgeb: Jahrb. für Wiss. Bot. $7: 357$. I867-70. In plate 23 , fig. 8 , is shown a sporangium with spores sprouting after the manner of Aplanes. This variation I have many times seen in an undescribed species of Dichtyuchus that is common at Chapel Hill.

Leptomitus lacteus (Roth) Agardh: Humphrey (Saprolegniaceae of the United States, etc.), says on page I36: "While the zoospores ordinarily escape from the sporangia, they sometimes become encysted within them (Fig. II7). It is this fact, probably, which led Braun to state (' $5 \mathrm{I})^{12}$ that the spores of Lepto-

12 This refers to A. Braun. Betrachtungen über die Erscheinung der Vorjungung in der Natur. Leipzig, $185 \mathrm{r}$. Also translated by Henfrey, Ray Society, London, 1853 . 
mitus are arranged in a row in the spore cases, and that 'no active gonidia seem to occur.,"

Monoblepharis macranda Woronin: Memoirs de l'Acad. Imp. des Sciences de St. Petersbourg. Cl. Phys. Natl. 8th series I6: I. 1904. In this species some or all of the spores may be retained in the sporangium and sprout there. Normally the zoospores on emerging show amoeboid movements.

Saprolegnia asterophora De Bary: Jahrb. für Wiss. Bot. 2: I69. I860. In plate 20 , fig. 25 , is shown a partly emptied sporangium, the remaining spores sprouting into tubes.

Saprolegnia ferax (Gruith.) Thuret: Ann. Sci. Nat. III. I4: 2 I4. I850. In plate 22, fig. 8, Thuret shows an unopened sporangium with the spores sprouting in position. This is a good example of the Aplanes method.

In the case of a parasite on fish, that he considers Saprolegnia ferax, Smith gives a figure showing spores sprouting inside the sporangium at one end while others are swimming out at the other. Such a combination is probably fanciful (Grevillea 6: $\mathbf{I}^{2}$. 1878. The same in Gardener's Chronicle, 4th of May, I878).

In this same species Pringsheim (Jahrb. für Wiss. Bot. 9: I9I. I874) gives an interesting case (fig. I2, plate $2 \mathrm{I}$ ) of the contents of an egg turning immediately into a sporangium, the spores being retained and sprouting in position. In figs. $\mathrm{Ia}, \mathrm{b}, \mathrm{c}$, plate 20 , he shows spores that had been retained in a partly discharged sporangium. These had sprouted in position to short tubes which became sporangia and discharged small spores. ${ }^{13}$

Saprolegnia monoica Pringsheim: Huxley, Quart. Jour. Micr. Sci. 22: 3II. I882. He describes the regular occurrence towards the end of active growth of sporangia of the Aplanes type. $\mathrm{He}$ calls them, improperly, "dictiosporangia." In this plant, which was a parasite on salmon, it is noteworthy that Huxley found no motion in the spores but only a passive drifting about when discharged. In a similar (probably the same) plant, found as a parasite on fish, Anger (Ann. Sci. Nat. III. 2: 5. I844)

13 The assertion by Gerard (Proc. Soc. Nat. Hist. Poughkeepsie, December 18,1878, p. 25 ) of the occasional retention of the spores in Saprolegnia ferax is probably not based on any original observation. 
gives a figure (fig. II, plate I) showing a few spores left in the sporangium and sprouting there into long tubes. In this parasite he records the spores as swimming on leaving the sporangium, not floating away as in Huxley's plant.

Saprolegnia torulosa De Bary: Lechmere, New Phytologist 9: 305. I9I0. In fig. 33 , plate 2 , is shown a sporangium with spores sprouting after the manner of Aplanes. Another example is shown in the same journal ro: 167. I9I , fig. 2, on page 175 . In his first paper he shows that the second swimming stage may be suppressed. De Bary in Vergleichende Morphologie and Biologie der Pilse, Leipzig, I884, says (page II7) that the second swimming stage may be omitted in any species of Saprolegnia.

Saprolegnia sp.?: Pringsheim, Jahrb. für Wiss. Bot. 2: 205. I860. In plate 22 , fig. 9 , is shown a sporangium emptying exactly as in Dictyuchus. It is attached to a hypha which also bears a sporangium of the normal Saprolegnia type.

In both Saprolegnia and Achlya it frequently happens that the discharge of the spores is only partial, a few, or even a good many spores being left in the sporangium. These retained spores may emerge from their cysts, as normally, for a second swimming stage, moving about within the sporangium until they find their way out by its mouth. This is shown by Hildebrand for his Achlya polyandra (not $A$. polyandra De Bary) (Jahrb. für Wiss. Bot. $6: 249$. I867, plate I6, fig. 2) and by Lechmere for Saprolegnia torulosa (?) (New Phytologist 9: 305, plates I and 2. I9Io, figs. 22, 23, 30, 3I. Also in vol. Io, fig. 2, page I75). Lechmere erroniously calls this the Dictyuchus type of asexual reproduction. It is doubtful if the species of Saprolegnia (a parasite on fish) studied by him in his first paper is Saprolegnia torulosa. It is more apt to be the one that Huxley studied (Quart. Jour. Micr. Sci. 22:3II. I882) and supposed to be S. monoica.

Another peculiar and rare variation in the behavior of the sporangial contents is described and figured by Horn (Ann. Myc. 2: 207. 1904) for Achlya polyandra De Bary ( $A$. De Baryana Humphrey). At a temperature of $3 \mathrm{I}^{\circ}$ to $32^{\circ}$ Celsius, sporangia were formed which emptied large masses of protoplasm 


\section{$2 \mathrm{BHL}$ Biodiversity Heritage Library}

Coker, William Chambers. 1914. "Two new species of water molds." Mycologia 6(6), 285-302.

View This Item Online: https://www.biodiversitylibrary.org/item/192144

Permalink: https://www.biodiversitylibrary.org/partpdf/246931

\section{Holding Institution}

New York Botanical Garden, LuEsther T. Mertz Library

\section{Sponsored by}

BHL-SIL-FEDLINK

\section{Copyright \& Reuse}

Copyright Status: Public domain. The BHL considers that this work is no longer under copyright protection.

This document was created from content at the Biodiversity Heritage Library, the world's largest open access digital library for biodiversity literature and archives. Visit BHL at https://www.biodiversitylibrary.org. 